\title{
PENINGKATAN MUTU \\ PENDIDIKAN DENGAN \\ MENERAPKAN BERBAGAI \\ MODEL PEMBELAJARAN
}

\section{Nazmah Zahiroh, Amsal Masitha, Rizka Lailatul Fitriya}

Universitas Nahdlatul Ulama Sidoarjo

Email: nazmahzahiroh@gmail.com

titamasitha@gmail.com

rizkalailatul6@gmail.com

Undang-Undang RI No. 20 Tahun 2003 menyebutkan bahwa pembelajaran adalah sebuah proses yang dilaksanakan secara sadar pada setiap orang atau kelompok untuk merubah sikap dari tidak tahu menjadi tahu sepanjang hidupnya. Sedangkan proses belajar mengajar adalah kegiatan inti sekolah yang di dalamnya terjadi sebuah interaksi antara siswa belajar dan guru mengajar dalam konteks interaktif dan terjadi interaksi edukatif antara guru dan siswa, sehingga terdapat perubahan dalam diri siswa baik perubahan pada tingkatan pengetahuan, pemahaman dan keterampilan ataupun sikap. Melalui kegiatan mengajar tersebut akan dicapai tujuan 
pendidikan tidak hanya dalam hal membentuk perubahan tingkah laku dalam diri siswa, akan tetapi juga meningkatkan pengetahuan yang ada dalam diri siswa.

(Agus:2013) Model pembelajaran memiliki urgensi tinggi dalam pengorganisasian proses pembelajaran di dalam kelas secara aktif. Pembelajaran aktif menjadi teknik yang paling popular dalam dunia pembelajaran kekinian. pendapat yang digunakan pada pembelajaran aktif adalah siswa menjadi pelaku utama dalam proses belajar mengajar, sedangkan guru diposisikan sebagai contoh, pendamping, panutan, pengarah atau fasilitator. Hampir semua praktisi pendidikan percaya bahwa pembelajaran aktif akan menghasilkan output sekaligus peserta didik yang kreatif dan mampu menjawab dan menyelesaikan persoalan yang dihadapinya di dunia nyata. Selain itu, masa depan peserta didik menjadi tidak perlu diragukan lagi dikarenakan mereka sudah mampu mengelola secara aktif potensi yang dimiliki dalam diri masing-masing.

(Hamruni:2009) Model pembelajaran merupakan pola yang digunakan sebagai acuan dalam merancang pembelajaran di kelas maupun contoh. Model pembelajaran dapat diartikan sebagai kerangka konseptual yang menggambarkan langkah-langkah yang sistematis dalam mengorganisasikan 
pengalaman belajar untuk mencapai tujuan belajar.

\section{Pengertian Pendidikan}

(Sofan:2013) pendidikan adalah salah suatu bentuk kebudayaan manusia yang dinamis dan syarat perkembangan yang bisa berubah dan berkembang sejalan dengan perubahan budaya kehidupan. Pendidikan merupakan Penyampaian pembelajaran, pengetahuan yang dilkukan oleh individu atau kelompok yang dilaksanakan dengan berbagai cara atau model pembelajaran yang dirancang khusus sesuai dengan aturan yang telah ditentukan.

(Undang-Undang RI No. 20:2003) Pembelajaran adalah sebuah proses yang dilakukan secara sadar pada setiap orang atau kelompok untuk merubah sikap dari tidak tahu menjadi tahu sepanjang hidupnya. Pembelajaran merupakan suatu kegiatan interaksi guru dan siswa yang dilakukan dalam waktu yang telah ditentukan untuk mecapai tujuan tertentu.

Hubungan pendidikan antara guru dan murid itu seperti aliran listrik dengan lampu. Bagaimana lampu itu bisa menyala kalau aliran listriknya juga mati ?. Bagaimana murid 
itu bisa berprestasi sedangkan guru sendiri tidak pernah berprestasi dan mendoakan. Pendidikan adalah usaha yang dilakukan oleh seseorang kepada orang lain dalam mentransfer ilmu pengetahuan (Fidiana, et al., 2017). Dalam memanajemen lembaga pendidikan penting sekali menata niat untuk mendidik karena Allah SWT. Anak-anak dikenalkan dengan konsep tentang Allah, dan meyakinkan siswa bahwa niscaya rintangan sebesar apapun akan terasa ringan dihadapan kita. (Yuniarti et al., 2017). Guru harus bisa membangun generasi muda untuk masa depan. Generasi tersebut dituntut untuk belajar mengamalkan ilmu yang telah didapatkannya. Terus bekerja keras dan bersabar dalam menghadapi semua masalah. Seperti dalam Firman Allah, sesungguhnya didalam kesulitan ada kemudahan (Sholichah et al., 2017). Kita juga dituntut untuk mencari ilmu yang berguna serta menerapkan peaturan-peraturan yang ada dan bersikap bijaksana (Nahdiyah et al., 2017).

\section{Pengertian Model Pembelajaran}

(Sofan:2013) Model pembelajaran adalah suatu desain yang menggambarkan proses rincian dan penciptaan situasi lingkungan yang memungkinkan siswa dapat berinteraksi sehingga terjadi perubahan atau 
perkembangan pada diri siswa. Media pembelajaran adalah suatu cara yang disusun secara sistematis dengan ketentuan kurikulum yang sudah ditetapkan yang dapat dijadikan guru untuk salah satu cara menyampaikan materi kepada siswa.

(Hamruni:2009) Cara berpikir kita terhadap sebuah proses pembelajaran. Strategi merupakan rancangan atau rencana pembelajaran yang menyangkut semua hal yang terkait dengan pembelajaran. Metode merupakan cara yang dilakukan untuk menerapkan rencana. Sedangkan teknik merupakan gaya atau style khas yang diterapkan oleh guru dalam menjalankan metode. Strategi merupakan susunan atau rancangan pembelajaran yang mencakup semua hal yang berhubungan dengan pembelajaran metode adalah cara yang dilakukan untuk menerapkan susunan. Sedangkan teknik merupakan adalah model yang dilakukan guru untuk menjelaskan metode.

Didalam pembelajaran terdapat beberapa model pembelajaran yang bisa digunakan oleh guru untuk menyampaikan materi atau pelajaran yang dapat memudahkan guru untuk melakukan proses belajar mengajar dan siswa dapat lebih muda 
menerima apa yang disampaikan oleh guru. Kenapa model pembelajaran sangat dibutuhkan oleh guru dalam proses belajar mengajar? Karena didalam pendidikan ada kurikulum yang dipakai oleh guru dan dijadikan patokan dalam proses pembelajaran, dan model pembelajaran ini sangat membantu guru dalam melakukan interaksi dengan siswa. Dibawah ini merupakan salah satu dari beberapa contoh model pembelajaran.

\section{Macam-macam Model Pembelajaran}

(Hamruni:2009) Model pembelajaran discovery adalah proses interaksi siswa dengan lingkungannya dalam mengkonstruksi dirinya sendiri melalui pengamatan yang dilakukan oleh siswa tersebut. Siswa terkadang mengingat dan mentransfer informasi secara lebih efektif ketika mereka mengkonstruksinya sendiri ketimbang hanya membacanya atau mendengarnya. Pembelajaran discovery adalah suatu tahap bagi siswa berkomunikasi dengan sekitarnya dan mendapatkan pengetahuan bagi dirinya dengan mencari dan mencoba membuat objek atau eksperimen secara lebih terperinci. Siswa terkadang menalar pengetahuan yang diperoleh dan dituangkan kedalam dirinya dengan cara melihat atau mendengar. 
(Jerom:2006) mengembangkan belajar penemuan (discovery learning) yang berdasarkan kepada pandangan kognitif tentang pembelajaran dan prinsip-prinsip konstruktivis. Menurutnya, "belajar merupakan suatu proses aktif yang memungkinkan manusia untuk menemukan hal-hal baru diluar informasi yang diberikan kepada dirinya". Sedangkan menurut (Ruseffendi:2006) metode discovery learning adalah "metode mengajar yang mengatur pengajaran sedemikian rupa sehingga anak memperoleh pengetahuan yang sebelumnya belum diketahuinya tanpa pemberitahuan langsung sebagian atau keseluruhnya ditemukan sendiri. Discovery learning bisa dikatakan model atau metode berdsarkan para ahli, discovery learning adalah suatu tahap aktif yang dapat diterapkan kepada siswa untuk menumbuhkan rasa percaya diri agar siswa dapat menemukan hal yang baru dan dapat mendapatkan informasi yang lebih luas, anak akan lebih muda mendapatkan pengetahuan langsung secara bertahap dalam diri siswa. 


\section{Konsep dasar dan Strategi Pembelajaran Inkuiri}

(Rostiyah:2008) Konsep Dasar Pembelajaran Inkuiri, Inkuiri berasal dari kata to Inquire yang berarti ikut serta, atau terlibat, dalam mengajukan pertanyaan-pertanyaan, mencari informasi, dan melakukan penyelidikan. Selanjutnya (Mulyono:2011) berpandangan bahwa model pembelajaran ini sering juga dinamakan strategi heuristic, yang berasal dari bahasa Yunani, yaitu heuriskein yang berarti saya menemukan. Lebih lanjut ia mengatakan bahwa strategi ini menekankan pada proses mencari dan menemukan, sehingga materi pelajaran tidak diberikan secara langsung.

Peran peserta didik dalam strategi ini adalah mencari dan menemukan sendiri materi pelajaran, sedangkan guru berperan sebagai fasilitator dan pembimbing peserta didik untuk belajar. Pembelajaran inkuiri adalah susunan atau rencana pembelajaran yang lebih memfokuskan pada tahap berpikir kritis dan efisien untuk menentukan jawabannya sendiri dari suatu permasalahan yang ditanyakan. Tahap berpikir lebih luas itu biasa dilakukan dengan cara Tanya jawab antar siswa dan guru. 
(Mulyono:2011) Strategi pembelajaran inkuiri banyak dipengaruhi oleh aliran belajar kognitif. Dimana menurut aliran ini, belajar pada hakikatnya adalah proses mental dan proses berpikir dengan memanfaatkan segala potensi yang dimiliki setiap individu secara optimal. Belajar lebih dari sekedar proses menghafal dan menumpuk ilmu pengetahuan, tetapi bagaimana pengetahuan yang diperolehnya. Rencana pembelajaran inkuiri banyak dipengaruhi oleh tata cara belajar yang bertahap. Belajar pada dasarnya adalah cara berpikir dengan memannfaatkan semua keahlian yang ada dalam setiap individu secara intensif.

\section{Kesulitan yang muncul dalam proses pembelajaran}

Menurut (Abdul:2012) di dalam pendidikan tentunya terdapat proses belajar. Proses belajar dapat diartikan sebagai tahapan perubahan perilaku kognitif, afektif, dan psikomotor yang terjadi dalam diri siswa. Perubahan tersebut bersifat positif dalam arti berorientasi kearah yang lebih maju dari pada keadaan sebelumnya. Salah satu tahap belajar diartikan seperti runtutan perubahan sikap, tindakan, dan keaktifan yang timbul dari diri peserta didk, perubahan itu bersifat 
membangun yang berarti mengarah kepada hal yang lebih baik dari sebelumnya.

(Alim:2012)Bila ditelusuri secara mendalam, proses belajar mengajar yang merupakan inti dari proses pendidikan formal di sekolah yang di dalamnya terjadi interaksi antara berbagai komponen pengajaran. Komponen- komponen itu dapat dikelompokan ke dalam tiga ketegori utama, yaitu: Guru, Isi atau Materi Pelajaran, dan Siswa. Interaksi antara ketiga komponen utama itu melibatkan sarana dan prasarana, seperti metode, media, dan panataan lingkungan tempat belajar, sehingga terciptanya situasi belajar-mengajar yang memungkinkan tercapainya hubungan yang harmonis dan dinamis diantara guru dan siswa. Salah satu contoh Kesulitan belajar dalam membaca yang dialami oleh siswa sangat banyak sekali seperti banyaknya siswa yang kurang memahami bacaan, ide-ide pokok dari teks/wacana, dan sulitnya siswa menemukan kata kata yang sukar dalam bacaan tersebut. Dalam permasalahan belajar dalam membaca yang dialami oleh siswa dapat diberikan model pembelajaran yang sesuai dengan pelajaran tersebut.

(Robert:2009) Dengan adanya kesulitan belajar yang dialami oleh siswa SD kelas IV dalam memahami bacaan maka guru harus 
bisa mengatasinya atau mencari alternatif solusi dengan menggunakan metode Cooperative Integrated Reading and Composition. Cooperative Integrated Reading and Composition dapat dijadikan oleh guru untuk menyapaikan materi dalam permasalahan pembelajaran diatas, karena model tersebut dapat memudahkan guru dalam mengatasi masalah pembelajaran dan siswa lebih muda memahami karena cara penyampaian materi yang diterangkan oleh guru lebih menarik. (Nahdiyah K, 2018) menyatakan bahwa kurangnya model pembelajaran yang baik itu juga mengganggu proses belajar dan pembelajaran bagi anakanak yang sedang menimba ilmu di sekolah.

\section{Penutup}

Didalam pendidikan terdapat peraturan yang sudah ditetapkan dalam Undang-undang dan harus dipatuhi. Didalam proses belajar mengajar terdapat materi pembelajaran yang banyak sekali dan akan disampaikan oleh guru kepada siswa. Contohnya seperti sekolah yang menggunakan kurikulum 2013, dalam menyampaiakn materi guru dan siswa mendapatkan kesulitan belajar yang dapat diatasi dengan menggunakan berbagai macam model pembelajaran seperti Discovery learning, Cooperative Integrated Reading and 
Composition, Inkuiri. Ketiga model tersebut dapat digunakan oleh guru untuk menyampaiakan materi pembelajaran kepada siswa. Mengapa model pembelajaran dibutuhkan oleh guru dan siswa? Karena model pembelajaran disusun secara sistematis dan dikemas semenarik mungkin agar siswa lebih memahami materi yang disampaikan oleh guru dengan mudah.

\section{References}

Fidiana, W., Istiana, Z., Rosyidah, E.,

Purnomo, A. (2017). MINU Waru 2 Insan

Berkilau Cahaya Manfaat. In Wirausaha

Pendidikan Indonesia (Jilid 4). Sidoarjo:

Unusida Press.

Nahdiyah, K., Amrina, S., Purnomo, A., \&

Rosyidah, E. (2017). SD Taman

Pendidikan Islam Porong Iman Kuat Bekal

di Akhirat. In Wirausaha Pendidikan

Indonesia (Jilid 2). Sidoarjo: Unusida

Press.

Sholichah, S.A., Istiqomah, A., Rosyidah, E., \&

Purnomo, A. (2017). MI Darun Najah

Berfikir Berkarya Berdzikir. In Wirausaha

Pendidikan Indonesia (Jilid 3). Sidoarjo:

Unusida Press. 
Sirait, M. (2017). Model Pembelajaran

Berbasis Discovery- Inkuiri dan

Kontribusinya Terhadap Penguatan

Kualitas Pembelajaran di Sekolah Dasar.

Jurnal Pendidikan Dasar, Ar-Riayah, 1(2).

Studi, C., Iv, K., \& Rejang, S. D. N. (2017).

Upaya Mengatasi Kesulitan Memahami

Bacaan pada Mata Pelajaran Bahasa

Indonesia dengan Menggunakan Metode

Cooperative Integrated Reading And

Composition, 1(2).

Yuniarti, D., Kautsari, M.F., Sholichah, F., Purnomo, A., \& Rosyidah, E. (2017).

SMP SMA Al-Amin Ponpes Bahrul

Hidayah Serahkan pada Allah Ta'ala. In

Wirausaha Pendidikan Indonesia (Jilid 1).

Sidoarjo: Unusida Press. 